\title{
AUTO-ETHNOGRAPHIC TECHNIQUES AS AN EFFICIENT TOOL FOR RECONSTRUCTION OF RURAL SOCIAL CAPITAL AND LOCAL IDENTITY
}

Tomasz MARCYSIAK, WSB University in Torun, Faculty of Finance and Management in Bydgoszcz, Department of Social Sciences, ul. Młodzieżowa 31a, 87-100 Toruń, Poland, tomasz.marcysiak@ wsb.bydgoszcz.pl

Piotr PRUS, UTP University of Science and Technology in Bydgoszcz, Faculty of Agriculture and Biotechnology, Department of Economics and Advising in Agribusiness, ul. Fordońska 430, 85-790 Bydgoszcz, Poland, piotr.prus@utp.edu.pl

\begin{abstract}
Many regions in Poland are said to be a unique example of preservation of cultural heritage. These include many examples of Pomorskie, Kujawsko-Pomorskie, Wielkopolskie and Dolnoslaskie voivodships. These regions are known to preserve the traditional way of life and customs as well as the architecture, especially the sacral architecture. It is also much easier to build mutual trust and social capital in them, because people from those regions can always refer to the universal values of their ancestors. However, there are also regions which, under the influence of migration and post-displacement processes after World War II, have lost their cultural and social character. Economic emigrants and displaced people from the Eastern Borderlands and Central Poland shared poverty and desire to settle. Will they succeed, and is there a chance to recreate and build a new identity? Those are the questions we are trying to answer, and the following article presents some of the results. By moving the border of autobiographical and ethnographic methods, authors adopt an autoethnographic method (narrative interviews, participant observation, biographical methods), which means turning to narratives as a way of research and as an expression of the search for a different relationship between the researcher and the subject and between the author and the reader. The researchers use their own experiences as a source of description of the culture in which they participate and examine. As a result, the text is a story created by the local community and researchers, aimed at reproducing and creating identity in the post-immigrant rural communities based on experienced and historical memory. The research was conducted in the years 2016-2017 in the above mentioned voivodships.
\end{abstract}

Keywords: qualitative research, autoethnography, rural social capital, post-immigration societies identity

\section{INTRODUCTION}

According to the definition provided by Edmund Wnuk-Lipinski, civil society is "the entirety of non-state institutions, organisations and civil associations acting in the public sphere. These structures are relatively independent from the state and are grass-root initiatives that are generally characterised by voluntary participation of their members" (Wnuk-Lipinski, 2005, pp. 119). 1989 symbolically provided Poles with a sense of social subjectivity and control over their lives. According to Wnuk-Lipinski, only after subjectivity is recovered it is possible to "realistically consider the possibility to impact not only one's own life, but also the fate of community, to which one belongs" (Wnuk-Lipinski, 2005). This is a prerequisite for formation of a civil society. A civil society is a society "consisting of active citizens, who are concerned about the interests of the society, in which there are political dependencies based on the principles of equality and social relationships consisting in trust and cooperation" (Putnam, 1995). This ability to act in a civil society is measured by the level of social capital. According to James Cooleman, a social capital is "the ability of people to cooperate within groups and organisation in order to realise common interests" (Fukuyama, 1997). The human potential measured by the ability to group together in order to achieve a specific goal not only significantly impacts the economy, but also other aspects of social activity (primarily non-state organisations). Our goal was to investigate the degree in which autoethnography, as an information obtaining technique (Kacperczyk, 2014), may contribute to initiation and reinforcement of local activities of communities aimed to build a social capital and an attempt to recreate an identity in a new place based on historical experience of the oldest generation. The issues related to social mechanisms, the inhabiting and managing the lands regained by Poland after the Second World War still remain an important subject of study for sociologists, writers and regional trusts. The circumstances surrounding the early settlement such as the origin and identity of the settlers, the problems they encountered at the very beginning, and the documents they have left behind, were particularly interesting (Kwilecki, 2012). Our goals were twofold; on one hand we aimed to continue the study of the post-immigrant societies, and on the other we aimed to understand how the presence and work of the researchers influence and raise the people's interest in the history and the past of the region.

Copyright (C) 2017 The Authors. Published by Aleksandras Stulginskis University. This is an open-access article distributed under the terms of the Creative Commons Attribution License (CC-BY 4.0), which permits unrestricted use, distribution, and reproduction in any medium, provided the original author and source are credited. 
The last 10 years in Poland brought about a significant increase of social activity, at least according to Poles themselves (Boguszewski, 2016). As stated by Boguszewski, "more and more Poles show interest in matters going beyond their private lives, by attempting to e.g. influence the functioning of local communities" (Boguszewski, 2016). In turn, another report states that "Poles most often engage in unpaid work for widely understood family or activities associated with helping other persons, with whom they are well acquainted" (Badora, 2014). According to Diagnoza Spoleczna 2015, despite the fact that nearly $57 \%$ of households in Poland do not have any savings, the number of persons who positively evaluate their lives both in economic and personal aspect keeps growing (Czapinski and Panek 2015). Moreover, the authors of this cyclic research see minor signs of creation of civil society. Compared to the studies from previous years (Czapinski and Panek, 2001, 2004, 2006, 2007, 2009, 2011, 2013), the percentage of people who trust others has increased, along with a minor increase of sensitivity to violation of common good. Unfortunately, still nearly half of citizens is indifferent to acts of violation of public property. However, social capital indicators, i.e. tolerance and inclination to form associations, which have remained at one of the lowest levels in Europe since the beginning of transformation, not only failed to increase, but were subject to a minor drop (Czapinski and Panek, 2015). There are several reasons for that.

The aim of non-state organisations is to attract as many people who would spend their private time to achieve goals of an association, most often for the local society, as possible. Unfortunately, at certain point, goals may not be achieved without a certain level of reliability and professionalism, which in many cases mean the necessity to have a personnel. Regrettably, in Poland one of the barriers is the mentality, which is characterised by a belief that non-state organisations should act on a principle of voluntary and unpaid social action, and not as a good employer (Goszczynski et al., 2013). The second reason for low engagement in non-state organisations also results from this mentality. People are generally willing to help, in particular in crisis situations (natural disasters, fire etc.), but when it comes to support for initiatives with even small budgets (often coming from European funds), they become jealous and gain a belief that if someone is resourceful enough to obtain external funding, he or she does not need any help, because he or she already earns a lot of money on the initiative. There are even situations when people turn away from others who show more initiative than they do, and at the same time are more resourceful and enterprising - in other words, from people who can earn money from the initiatives. This is, however, not surprising. Alexis de Tocqueville already came to these conclusions, saying that "cases that would naturally attract a lot of people to common activity are rare in social life, and it is extremely difficult to create an interest that would be common for everyone" (Tocqueville, 1976).

Having regard to that, we came up with a hypothesis, in which, generally speaking, we found that local communities will be better organised and more engaged in solving their own (local) problems, if a given venture is even to a minimum extent supported by an external institution. By external institutions we mean the research institutions, the authority of a scientist, universities, agricultural advisory centres etc. It seems that the belief that contemporary social capital is impacted not only by grass-root initiatives of residents, but also their mutual trust and financial support of external institutions (village administration funds, participation budgets, restricted grants from the European Union Funds) is not innovative. However, people are more eager to cooperate in matters going beyond personal interest when they share a bond based on a strong sense of identity. For this reason, we assumed that in places where local identity is for various reasons impaired (for example due to lack of common references to historical memory), development activities will be aimed towards a selected group of recipients (sharing common identity) or, by standard, towards development of an infrastructure.

The research adopts an auto-ethnographic approach, which has its roots in the best traditions of global biographical sociology, starting from Florian Znaniecki and William Thomas, through their followers: Jozef Chalasinski, Stanislaw Rychlinski or Duda-Dziwierz (Thomas and Znaniecki, 1923; Rychlinski, 2001; Duda-Dziwierz, 1938). The research based on triangulation and saturation of information about an event, the illustration of which are personal documents, indepth narrative interviews, letters, photographs, journals is what marks the beginning of a narrative ethnography, or as it is called today - the autoethnography. Narrative ethnography (autoethnography) relates to texts presented in a form of a story, which take into account experiences of an ethnographer in the ethnographic descriptions of other researchers. Another important aspect of the ethnographic research is the reflectiveness of the researcher, and thus, despite focusing on the participant of the study and his or her history, it also takes into account the thoughts and feelings of the researcher. E.g. the reason why the researcher executes a given research project, what was his or her motivation, what is his or her knowledge about a given field and how it changed over the course of the study. Despite the fact that the researcher's experience is not the main goal, his or her personal afterthoughts provide the story with a context and as a result impacts the final illustration of the participants of the study (Ellis et al., 2010). Such an approach is also close to assumptions of the grounded theory methodology, where collection and analysis of data is carried out at the same time in real-time (Charmaz, 1983, pp. 110).

\section{RESEARCH METHODS}

Nearly 30 years of transformation in Poland shows the diversity and complexity of its cultural reality. For this reason, it can be described and analysed using various methods. On the one hand, contemporary researches have a large number of concepts, researched methods and theoretical approaches at their disposal. On the other hand, we observe significant attachment to quantitative methods, the results of which are often presented in shortened, although attracting attention charts or graphs. However, it is difficult to resist the impression that diagnoses where also subject to simplification, and the ground and work have been put to a single bag and are treated as commodity. We draw these conclusions on the basis of participation 
in research seminars of Instytut Rozwoju Wsi i Rolnictwa Polskiej Akademii Nauk (Institute of Rural and Agricultural Development of the Polish Academy of Sciences), where allegations that a Polish researcher (sociologist) is first and foremost a diligent reader of Western texts, and only subsequently an originator of new research directions are not uncommon. We are in the middle of this thesis, since, on one hand, we are inspired by how our colleagues from the West develop autobiographical methods, while on the other, we constantly confront our experiences and knowledge during field work in direct contact with actors of social life. Also, we never summarise statements of our interlocutors in statistical bars or mark them with one of many points of a prepared scale. The case is so captivating and inspiring that the authors of this elaboration represent completely different approaches in terms of research: some of us prefer quantitative research methods (Prus and Drzazdzynska, 2017), while the other (Marcysiak, 2015) stubbornly holds on to Florian Znaniecki postulate, according to which the society should be studied in its natural cultural context, in an apartment, in the yard, or even on a bench in the park, following the rule of "humanistic coefficient" (Znaniecki, 2001). As explained by Znaniecki, "the most important, general feature of items and facts studied by a humanist is the fact that they belong to someone, that is they exist in actions and experience of certain people and have the properties given to them by those acting and experiencing people in their actions and experiences" (Znaniecki, 2001). This text discussed merely a fragment of a wider research, which aimed to diagnose the identity of post-immigration societies. We chose ethnographic and sociological methods as those that provide the most appropriate range of tools and techniques, which, above all, may be adapted and changed in real time depending on the situation and place we find ourselves in. This manner of research has already proven itself in a project aimed at diagnosing the level and quality of lives of a selected commune in Bory Tucholskie. The specificity of place, people and resources allowed us to develop research tools, which enabled us to successfully test data collection techniques such as free interview, narrative interview, memoir contest, participating observation etc. (Marcysiak, 2015; Marcysiak and Prus, 2017). Both previous and current researches aim to maintain the tradition of Chicago school, which was based on a philosophy of pragmatism, which even now, and not only in our opinion (Charmaz, 2009), significantly enriches the discussion regarding the theory of social phenomena. From our point of view, it is particularly important to present the perspective of participants of researches and the researchers themselves. Therefore, we feel that the autoethnographic method will be the most appropriate in this case.

Autoethnography is an approach to research and manner of presentation of obtained results aiming to describe and analyse personal experiences and as a result attempting to understand cultural experiences. Autoethnographic method description is a combination of concepts from the scope of autobiography and ethnography. Therefore, the autoethnographic method is a process and product at the same time, and the researcher is a creator and a material, since his or her personal experience also plays a key role in this method. The autoethnographic method consists in personal narrations and interactive interviews and its main feature is appreciation of subjectivity and emotions (Ellis et al., 2010) that should not be hidden by pretending that the researcher does not experience them during an interview. Autoethnography is an extension and opening of a wide perspective on the world by avoiding absolute definitions of what makes a research work useful (Ellis et al., 2010). Commitment in autoethnographic research of a local community may positively impact the sense of identity. In practice, it may be treated (autoethnography) as a mechanism of social intervention in the construction or reconstruction of a social capital. Narrations of more than one person also provide an opportunity to confront knowledge and memories. They may be provided not only in a form of oral message (narrative interview), but also in a form of written experiences from the past.

Our experience shows that this method attracts great interest among small local societies, which, due to presence and commitment of researches, gain a new understanding of their history and the history of the place they live in (these are post-immigration societies) and become more eager to develop their village by shifting the burden of initiatives from the development of infrastructure to the culture and recovery of local identity. As of 31 December 2013, there were 40583 villages in Poland (Maly Rocznik Statystyczny, 2015). According to the study by Gawlowski and Sobolewska covering use of village administration funds among representative sample of communes, it may be stated that $60 \%$ of funds has been allocated to culture. Remaining funds were mainly allocated to small infrastructure investments (Gawlowski and Sobolewska, 2017). Therefore, it can be observed that villages do not only invest in commune infrastructure, but also in cultural development. Having regard to this, we decided to check whether the participation of researches, the presence of whom is indeed seen by local society, may contribute to the increase of the interest of village residents in actions aimed to recover local identity, or at least in the increase of commitment in creation of new local development programs.

\section{RESEARCH RESULTS}

The area of our research was very extensive, and the most remote villages we reached were located at the distance of $454 \mathrm{~km}$ from each other (Ksawerow and Ostrowite). In total, we visited 43 villages and towns from 4 voivodships: Pomorskie, Kujawsko-Pomorskie, Wielkopolskie and Dolnoslaskie, where we registered over 40 hours of autobiographical interviews. Therefore, we found for ourselves how real becomes the saying "all people in the world are separated by merely six handshakes" (Grzebalkowska, 2015). All villages are located on the territory of so called Recovered Territories, which have been given to Poland after the Second World War. However, according to Osękowski, the most important is the fact that "for a large group of Poles those lands left by Germans where an incredible opportunity. Many people came here from overpopulated villages of Kieleckie, Warszawskie, Lodzkie or Rzeszowskie voivodships. These territories gave an opportunity to obtain a farm, good land and life stabilisation" (Biuletyn..., 2005). An opportunity which also meant huge problems with adaptation. Stanislaw Jankowiak said that "for many people the new things they found here were so drastically different from their beliefs that they had not felt good in this new home" (Biuletyn..., 2005). If we add a cultural landscape 
of the new place, which was full of centuries-old German order, the cultural shock could be (and was) enormous. German churches, cemeteries, mills, factories, railway bridges, typical yards with large barns and cowsheds as well as fields often arranged all the way to the horizon; all this was very different from the memories of whitewashed houses, backward infrastructure and primitive farming culture. Therefore, some of them adapted quickly in the new place, while others, unfortunately, demolished what they found there in order to give the neighbourhood a new (more homely) nature. Even greater internal struggle was experienced by families that have been relocated to German houses, which have not been yet abandoned by their previous residents. It is hard to imagine today, but there were such situations. Germans have been living with Poles under one roof or even in single room for several days (Biuletyn..., 2005).

The short historic and cultural background of Polish villages of the researched area presented above is a perfect territory for autoethnographic studies. It is the written biographies (although fragmentary) that allow us to show the residents their true relationship and common roots. These mainly consist of the past marked with the resettlement, expulsion and flight. This is especially important, since we are the last generation that may have a family member who bases his or her historical memory on personal experiences. This memory changes a statistics of millions into an individual suffering of a single, specific person, with whom we can identify to gain better understanding of our own history. After preparing empirical materials (presentation, photos, fragments of interviews), we come back to the villages, in which we conducted the research and meet with residents and local leaders. It turns out that many did not know that their village has such an interesting history, the heroes of which are ordinary people (their neighbours). This in turn directly translates (although not always) to the change of approach and attitude towards projects of development of their own villages by transferring the burden of institution from material infrastructure (roads, lightning) to investments in social capital (meetings, talks, calendars, writing history, talks about photographies).

In all villages, in which we conducted the research, development initiatives were already taken, which were nearly always managed by someone from inside of a given community. However, the atmosphere of actions and contexts were very different. Starting in Bielawa Dolna, we observed on increased interest of residents with the history of their village only during regular presence of a group of archaeologists, who studies remains of the Tormersdorf village. Commitment of archaeologists attracted a great interest, making anonymous residents bring artefacts found by them to the place of excavation, for example a nearly 100-years old cross from the studied necropolis (Marcysiak et al., 2017). We observed a similar mechanism during our research. Announcement of a research visit not only raised an interest, but also resulted in finding further interviewers, who were recommended and wanted to share their biography. The difficulty of the whole situation and at the same time its uniqueness consisted in the fact that the last interlocutor from this region was already 94 years old. The residents nearly always ask for the same thing: "if your write something, please let us read it too." Other positive effect of collection using biographic methods were invitations to public presentation, during which the results of research were reported as a part of informal meetings with the residents of the villages. In one of them in Bochlima, residents summarised the research results in the following manner: "we had no idea that you could write so much about us and that our history is so interesting (...) who would have thought." Researches in further villages in the territory called Kosznajderia brought about essentially what is the most important feature of the auto-ethnographic method, that is commitment of the residents in searching information, material artefacts from the past and persons who can tell something about the history of the place they live in. This is important, since in Kosznajderia, which includes 20 villages, there are nearly no autochthons in senior age. They are all descendants of migrants of the time of the Second World War. Today, they say the following words about their villages (despite the fact that they belonged to German families, and not their families): "we do not know the people who lived here before us, we were raised in houses built by them, and our parents worked on lands cultivated by Germans with a very high level of agriculture." Unfortunately, our research also discovered negative changes in the villages. We made the most important observations in towns characterised by very low level of social capital. Residents seemed to barely know each other, despite the fact that they grew up together. Lack of bond manifested itself by little knowledge (or distrust) in indicating any interlocutors, and those indicated did not want to talk with us. The most grieving situation was the example of the integrated kindergarten, which raised a lot of interest in the initial phase of creation. This interest declined nearly entirely when the founders received the first funds from the EU. No one cared that the money was not kept by the originators, but was being spent on expansion of facilities and further rooms.

One more picture emerged from the collected data - reproduction of the mentality of the ancestors. Lands of recovered territories took an enormous toll on new settlers, who were told "that this your land, but who knows for how long" and that "either Germans return here one day, or the communists will take the most precious parts away." So, what could they do? Nothing. So, they did nothing. Farms, palaces, farmsteads and mills went to ruin, were devastated or demolished. Not even tombstones were spared - they were used as a base for tractor wheels or rubble. Today, many places need an archaeologist rather than a sociologist or an ethnographer. However, in our opinion, interdisciplinary teams can be quicker and more effective in saving remnants of non-material culture from obscurity, and can help local communities to recover their identity.

\section{CONCLUSIONS}

We are not sure whether collecting information using autoethnographic method in the most efficient manner of activation of local communities, but we are certain that it does work and if the idea of searching for common roots attracts enough interest, it will be continued by subsequent generations, giving a significant foundation for a new identity. Biographies and long-forgotten accounts from the life of a local community constitute valuable sources of empirical data. By bringing them to light, people can feel that they matter and become truly involved in the study. This identity will allow 


\section{Proceedings of the $8^{\text {th }}$ International Scientific Conference Rural Development 2017}

people to say: "this is our land and we are proud of that." Autoethnography is not only an effective, but also an attractive form of development of identity by local societies, since it engages all generations, and the representatives of the oldest one, to put it simply, do not even have to leave their houses. Maybe the recovery or creation of an identity in postimmigration societies is not a very difficult task, but it requires commitment of researchers in this very moment, when the first generation of settlers of the Recovered Territories is still alive. The settlers, whose memory is based on experiences, and not only historical knowledge or family stories.

\section{REFERENCES}

1. Badora, B. 2014. Aktywnosc spoleczna Polakow (Social activity of Poles). Fundacja Centrum Badania Opinii Społecznej. Komunikat z badan, No 60, Warszawa. [In Polish]

2. Biuletyn Instytutu Pamieci Narodowej - Polski Dziki Zachod (Bulletin of the Institute of National Remembrance - Polish Wild West). 2005. No 9-10. Available at https://ipn.gov.pl/download/1/18109/biuletyn1-260-61.pdf (Accessed on 16/11/2017) [In Polish]

3. Boguszewski, R. 2016. Aktywnosc Polakow w organizacjach obywatelskich (The activity of Poles in civic organizations). Fundacja Centrum Badania Opinii Spolecznej. Komunikat z badan, No. 13, Warszawa. [In Polish]

4. Charmaz, K. 1983: The grounded theory method: An explication and interpretation. In: Robert M. Emerson, R.M. (Ed.), Contemporary field research: A collection of readings. Prospect Heights, IL: Waveland, pp. 109-125.

5. Czapinski, J., Panek, T. (ed.). 2015: Diagnoza Spoleczna 2015. Warunki i Jakosc Zycia Polakow (Social Diagnosis 2015. Conditions and Quality of Life of Poles). Rada Monitoringu Spolecznego. Warszawa. [In Polish]

6. Duda-Dziewierz, K. 1938. Wies malopolska a emigracja amerykanska. Studium wsi Babica powiatu rzeszowskiego (The Małopolska Countryside and American Emigration. A Study of Babica, a Village in the Rzeszów District). Polski Instytut Socjologiczny, Vol. 3, Warszawa-Poznan. [In Polish]

7. Ellis, C., Adams, T.E., Bochner, A.P. 2010. Autoethnography: An Overview [40 paragraphs]. Forum Qualitative Sozialforschung / Forum: Qualitative Social Research, Vol. 12(1), Art. 10. Available at http://nbn-resolving.de/urn:nbn:de:0114-fqs1101108 (Accessed on 16/11/2017)

8. Fukuyama, F. 1997. Zaufanie. Kapital spoleczny a droga do dobrobytu (Trust. The Social Virtues and The Creation of Prosperity). PWN. Warszawa. [In Polish]

9. Gawlowski, R., Sobolewska, A., 2017. Fundusz solecki. Przepisy prawne i zasady wdrozenia (Solecki Fund. Legal provisions and implementation rules). Wyd. C.H.Beck, Warszawa. [In Polish]

10. Goszczynski, W., Kamiński, R., Knieć, W. 2013. Dylemat linoskoczka, czyli o profesjonalizacji autentycznosci i perspektywach rozwoju organizacji pozarzadowych na wsi i w malych miastach (The dilemma of a tightrope walker, the professionalization of authenticity and prospects for the development of non-governmental organizations in the countryside and in small towns). Wydawca Forum Aktywizacji Obszarow Wiejskich. Torun-Warszawa. [In Polish]

11. Grzebalkowska, M. 2015. 1945 Wojna i Pokoj (1945 War and Peace). Wydawnictwo AGORA. Warszawa. [In Polish]

12. Kacperczyk A., 2014. Autoetnografia - technika, metoda, nowy paradygmat? O metodologicznym statusie autoetnografii (Autonatography - technique, method, new paradigm? About the methodological status of autoattography). Przeglad Socjologii Jakosciowej, Vol. 10 (3), pp. 32-74. [In Polish]

13. Kwilecki, A., 2012. Z Kwilcza rodem (Straight from Kwilicz). Wydawnictwo Nauka i Innowacje. Poznań. [In Polish]

14. Maly Rocznik Statystyczny Polski 2015 (Small Polish Statistical Yearbook 2014). Glowny Urzad Statystyczny. Warszawa. [In Polish]

15. Marcysiak, T. 2015. Życie społeczne w gminie Cekcyn. Szkic socjologiczny (Social life in the municipality of Cekcyn. Sociological sketch). WSB, Torun. [In Polish]

16. Marcysiak T., Pretkiel I., Raszkowska A. 2017. Between Sociology and Archaeology - On Advantages of Interdisciplinary Research in Villages of Former Recovered Territories. Torun Social Science Review, Vol. 3, No 2, pp. 11-21.

17. Marcysiak T., Prus P. 2017. Life strategies of rural inhabitants of unfixed economic function. Proceedings of the 26th International Scientific Conference Agrarian Perspectives XXVI "Competitiveness of European Agriculture and Food Sectors", pp. 212-218, Czech University of Life Sciences Prague, Faculty of Economics and Management.

18. Prus, P., Drzazdzynska, K. 2017. Farmers' Assessment of Training Services and the Impact of Agricultural Advisory on Selected Developmental Factors Affecting Farming. Proceedings of the 2017 International Conference "Economic Science for Rural Development", No 44, Jelgava, pp. 338-344, Latvia University of Agriculture.

19. Puntam, R. 1995. Demokracja w dzialaniu (Democracy in action). ZNAK, Warszawa. [In Polish]

20. Rychlinski, S. 2001. Lustracje Spoleczne (Social Inspection). Instytut Polityki Spolecznej i Oficyna Wydawnicza ASPRA-JR. Warszawa. [In Polish]

21. Thomas, W.I., Znaniecki, F. 1923. The Polish peasant in Europe and America: monograph of an immigrant group: Volume III. Life-Record of an Immigrant. Albert R. Mann Library. 2014. Core Historical Literature of Agriculture (CHLA). Ithaca, NY: Albert R. Mann Library, Cornell University. http://chla.library.cornell.edu Available at http://chla.library.cornell.edu/cgi/t/text/pageviewer-

$\underline{\mathrm{idx}}$ ?c=chla;cc=chla;idno=3074959_2386;node=3074959_2386\%3A1;frm=frameset; iew=text;seq=7;page=root;size=s Accessed on $16 / 11 / 2017$ )

22. Tocqueville, A. 1976. O demokracji w Ameryce (About democracy in America). PIW, Warszawa. [In Polish]

23. Wnuk-Lipinski, E. 2005. Socjologia życia publicznego (Sociology of public life). SCHOLAR. Warszawa. [In Polish]

24. Znaniecki F. 2001. Socjologia wychowania (Sociology of education). Wydawnictwo Naukowe PWN, Warszawa. [In Polish] 